\title{
Юрислингвистика
}

Legal Linguistics, 2019, 11, 29-32, doi: https://doi.org/10.14258/leglin(2019)1106

ЛИНГВОЭКСПЕРТОЛОГИЯ

\section{Анализ прецедентного высказывания в рамках судебной лингвистической экспертизы: зарубежный и российский опыт}

\author{
Э.В. Будаев', М.Б. Ворошилова², А.П. Чудинов³ \\ ${ }^{1}$ Нижнетагильский государственный социально-педагогический институт (филиал) ФГАОУ ВПО \\ «Российский государственный профессионально-педагогический университет». 622031,

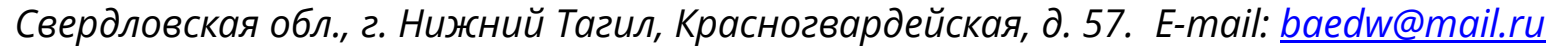 \\ уральский институт управления Российской академии народного хозяйства и государственной \\ службы при Президенте РФ. 620144, Свердловская область, \\ 2. Екатеринбург, ул. 8 Mapma, д.66, ка6.54, 28. E-mail: shinkari@mail.ru \\ Зуральский государственный педагогический университет, 620017, Свердловская область, \\ г. Екатеринбург, пр. Космонавтов, д. 26, каб.285 E-mail: ap chudinov@mail.ru
}

Дискуссия о правомерности лингвистической экспертизы прецедентных высказываний занимает значимое место в современном научном дискурсе. С одной стороны, прецедентные и метафорические высказывания часто становятся предметом судебных разбирательств, с другой - данные языковые факты нередко вызывают трудности в практике лингвистической экспертизы, потому что лексико-семантический уровень языка в меньшей степени, чем фонетический, морфологический или синтаксический уровни, поддается формализации.

Опыт выполнения подобных экспертных исследований есть как в российской, так и в зарубежной практике. В статье рассматриваются два примера анализа высказываний, содержащих лексику с переносным значением, один из которых демонстрирует особенности лингвистической экспертизы подобных выражений в британской судебной практике, а второй - отражает опыт рассмотрения схожих словосочетаний в российской лингвистической экспертизе. Особенности лингвистической экспертизы в обеих странах обусловлены различиями в процедуре проведения экспертизы и задачах, которые суд ставит перед экспертом.

В Британии вопрос о том, является ли какое-либо метафорическое прецедентное выражение клеветническим или нет, определяется с помощью двухэтапного процесса. На первом этапе судья решает, может ли рассматриваемое выражение потенциально содержать клевету. Решение принимается на основе так называемого теста «обычного читателя» (ordinary reader test). На втором этапе истец приводит свои аргументы, а затем бремя опровержения аргументов истца переходит к ответчику, который должен убедить судью и / или присяжных, что рассматриваемая фраза содержит правдивые данные. Помощь лингвиста привлекается только на первом этапе юридического процесса. В российской же практике лингвист должен рассмотреть форму выражения негативной информации и ответить на вопрос, может ли прецедентное высказывание быть частью утверждения о факте.

Ключевые слова: прецедентные феномены, прецедентные высказывания, судебная лингвистическая экспертиза.

Forensic Linguistics

\section{The analysis of the precedent expression within forensic linguistic expertise: Russian and international experience}

\author{
Budaev E.V. ${ }^{* 1}$, Voroshilova M.B. ${ }^{2}$, Chudinov A.P. ${ }^{3}$
}




\section{${ }^{1}$ Nizhny Tagil branch of Russian State Vocational Professional University \\ 622031, Sverdlovsk Oblast, Nizhny Tagil, Krasnogvardeyskaya 57. E-mail: aedw@mail.ru \\ ${ }^{2}$ Ural Institute of Management - branch of Russian Presidential Academy \\ of National Economy and Public Administration \\ 620144, Sverdlovsk Oblast, Ekaterinburg, st. 8 Marta,66-54. 28. E-mail: shinkari@mail.ru \\ ${ }^{3}$ Ural State Pedagogical University \\ 620017, Sverdlovsk Oblast, Ekaterinburg,av. Cosmonavtov, 26-285. E-mail: ap chudinov@mail.ru}

The discussion on the relevancy of linguistic expertise of precedent expressions looms large in contemporary scholarly discourse. On the one hand, precedent and metaphorical expressions are often cases at legal proceedings. On the other hand, linguistic phenomena of this kind often cause difficulties in for linguistic expertise, because it is more difficult to formalize the lexico-semantic level of the language than the phonetic, morphological or syntactic levels.

Both Russian and foreign linguists have experience in performing expertise of such expressions. The article discusses two examples of the analysis of statements containing vocabulary with a figurative meaning, one of which demonstrates the peculiarities of linguistic expertise of precedent expressions in British judicial practice, and the second one reflects the experience of considering similar phrases in Russian linguistic expertise. The peculiarities of linguistic expertise in both countries are caused by differences in the expertise procedure and the tasks that the court sets for the expert.

In Britain, the question of whether a metaphorical precedent expression is defamatory or not is determined through a two-step process. At the first stage, the judge decides whether the expression in question may potentially contain libel. The decision is made on the basis of the so-called "ordinary reader test". At the second stage, the claimant gives his arguments, and then the burden of refutation of the arguments of the claimant passes to the respondent, who must convince the judge and / or jury that the phrase in question contains truthful data. The linguist's help is involved only at the first stage of the legal process. In Russian practice, however, a linguist must consider a form of expressing negative information and answer the question whether a precedent expression can be part of a factual statement.

Key words: precedent phenomena, precedent expressions, forensic linguistic expertise.

В современном научном дискурсе активно развивается дискуссия о возможностях лингвистической экспертизы, в том числе, о правомерности анализа значения метафорического или прецедентного высказывания, которые все чаще становятся предметами судебных разбирательств [Будаев и др. 2017]. Эксперт, который руководствуется принципом всесторонности и полноты исследования (определенном в Ф3 №73), обязан проанализировать данные примеры и дать их точную оценку. Но наличие нескольких значений в любом метафорическом образе зачастую становится камнем преткновения в судебной практике. «Метафорические номинации могут влечь негативную оценку, но и в этом случае часто (впрочем, не всегда) точная вербализация негативной составляющей затруднена, - отмечают исследователи [Баранов URL]. Действительно, лексикосемантический уровень языка в меньшей степени, чем фонетический, морфологический или синтаксический уровни, поддается формализации, что приводит к определённым сложностям, особенно в практике проведения экспертизы. Нередко семантический анализ требует от специалиста широких познаний о методологическом багаже лингвистической науки и практических умений в реализации существующих в языкознании эвристик.

Но опыт выполнения подобных экспертных исследований есть как в российской, так и зарубежной практике. Успешным примером в зарубежной практике является комплексная методика, описанная А. Дюрантом на примере анализа прецедентного высказывания «экономить на правде» (be economical with the truth) [Durant 1996].

В британский суд обратился известный бизнесмен с иском против СМИ, которое в редакционной статье использовало при его характеристике слова «экономит на правде». Предприниматель в своем заявлении утверждал, что выражение «экономит на правде» имело смысл бесчестного сокрытия информации, что наносило ущерб его профессиональной репутации. В защиту статьи издатели выдвинули тезис о том, что не нужно рассматривать это словосочетание в понятиях истинности или ложности. Более того, издатели утверждали, что выражение «экономит на правде» является похвалой, а значит, не может нести уничижительного смысла.

Для решения поставленной задачи А. Дюрант обратился к пяти источникам:

1) конкордансы художественной литературы (для более полного представления о происхождении выражения);

2) Оксфордский словарь английского языка и иные лексикографические издания (чтобы проследить исходные и современные конвенциональные смыслы рассматриваемого выражения);

3) стенограмма судебного заседания, которое проходило в Сиднее по поводу книги Spycatcher в 1986 г. (в стенограмме представлен самый известный случай использования выражения «экономить на правде»; данная фраза была произнесена в свидетельских показаниях барона Роберта Армстронга); 
4) два корпуса английского языка: корпус Financial Times за 1983-1992 гг. и корпус английского языка (с материалами до 1986 г.), поддерживаемый Университетским колледжем Лондона;

5) материалы опросов 12 англоговорящих респондентов, полученные в ходе психолингвистического эксперимента.

Анализ показал, что исторически словосочетание есоnomical with the truth соотносилось с творчеством двух авторов. Первый из них - Марк Твен, которому принадлежит парадоксальная фраза «Truth is the most valuable thing we have. Let us economise it» («Истина - самое ценное, что у нас есть. Давайте её экономить»). В таком юмористическом ракурсе, человек, «экономящий истину», считает ее высшей ценностью, что едва ли можно рассматривать в уничижительном аспекте. Второй кандидат на авторство - Эдмунд Берк, англо-ирландский парламентарий, политический деятель и публицист эпохи Просвещения, которому принадлежит фраза «l do not impute falsehood to the Government, but I think there has been considerable economy of truth» («Я не утверждаю, что правительство нас обманывает, но думаю, что оно сильно экономит на правде»). В этой фразе Э. Берка прослеживается имплицитная критика властей.

Вместе с тем широкое распространение в английском языке фраза economical with the truth получила после ее использования сэром Робертом Армстронгом, британским секретарем кабинета министров, принимавшем участие в судебном разбирательстве по поводу книги П. Райта «Spycatcher» (в этой книге автор утверждал, что руководитель британской разведки МИ-5 был агентом КГБ, что привело к запрету ее публикации в Великобритании). Хотя ни отдельные слова, составляющие эту фразу, ни фраза в целом не были новыми (Роберт Армстронг предварял использование фразы словами: «как сказал один человек»), выражение вошло в употребление как своего рода неологизм, что было подтверждено в психолингвистическом эксперименте.

Тест «обычного читателя» показал, что двум третям респондентов была хорошо знакома фраза есоnomical with the truth из СМИ, а треть испытуемых сами использовали ее в своей речи. Когда же испытуемым предложили выбрать, с кем из двенадцати персоналий у них ассоциируется фраза есonomical with the truth, ни один из них не выбрал Марка Твена или Эдмунда Берка. Четверть опрашиваемых указала на Роберта Армстронга, а второй по популярности вариант ответа - «Ричард Никсон» (последний прочно ассоциируется в сознании англоговорящих респондентов с деловым мошенничеством, выявленным в ходе Уотергейтского скандала).

Вторая часть эксперимента была связана с семантической интерпретацией прецедентного высказывания.

10\% опрашиваемых отметили, что данная фраза привносит смысл краткости изложения, в то время как 80\% респондентов настаивали на том, что в содержании данного словосочетания есть смысл преднамеренного обмана. После этого А. Дюрант предложил респондентам оценить, как они отнеслись бы к такой фразе, если она была бы высказана в их адрес. 4\% расценили бы это как похвалу, 13\% как нейтральное высказывание, 80\% - как критику или оскорбление.

Корпусный анализ текстов до 1986 г. (корпус Университетского колледжа Лондона) не выявил ни одного совпадения с фразой есоnomical with the truth, в то время как в корпусе текстов 1986-1992 гг. (Financial Times Business Service Corpus) данное словосочетание встречается 450 раз. Таким образом, высказывание economical with the truth стало прецедентным после того, как ее использовал в судебном заседании Роберт Армстронг при описании действий британского правительства. Этот факт подтверждается еще и тем обстоятельством, что в конкордансах анализируемой фразы часто встречаются прямые указания на Роберта Армстронга как автора высказывания. Контексты актуализации данного прецедентного высказывания в корпусе свидетельствовали о пейоративном оценочном смысле. В одном из примеров в корпусе даже была предложена оценочная шкала, согласно которой «экономящий на правде» заслуживает максимально негативной оценки (The Good, The Bad, The Ugly and The Economical with the Truth - Хороший, Плохой, Мерзкий, Экономящий на правде).

Таким образом, опираясь на многоаспектный анализ прецедентного высказывания, А. Дюрант пришел к заключению, что данная фраза означает преднамеренное введение в заблуждение, искажение фактических данных или утаивание информации о существующем положении дел. Данная фраза начала жизнь как эвфемизм, но впоследствии стала образным выражением, означающим обман, особенно связанный с сокрытием дискредитирующего или непрофессионального поведения людей на государственной службе. Хотя сам лорд Р. Армстронг впоследствии утверждал в одном из интервью, что выражение economical with the truth означает «не предавать огласке данные, которые могут негативно восприниматься обществом», интервьюер, которому он изначально предложил это мнение, констатировал, что для большинства людей эта фраза уже стала эвфемизмом лжи.

Пример экспертизы, проведенной А. Дюрантом, наглядно демонстрирует, что для решения поставленной задачи эксперту необходимо владеть довольно широким арсеналом методов анализа, восходящих к различным направлениям лингвистической науки (в данном случае корпусной лингвистике, психолингвистике, этимологии, диахроническому анализу, дискурсивному анализу). Данная методика может быть использована и на примере русского языка, но задача российского эксперта немного шире.

Чтобы понять разницу функции лингвистов-экспертов, необходимо представлять в целом процедуру рассмотрения дел в британских судах. Является ли какое-либо выражение клеветническим или нет, определяется с помощью двухэтапного процесса. На первом этапе судья решает, может ли рассматриваемое выражение потенциально содержать клевету. Решение принимается на основе так называемого теста «обычного читателя» (ordinary reader test).

Далее истец должен продемонстрировать три вещи: во-первых, слова, которые послужили причиной обращения в суд, дискредитируют истца; во-вторых, что слова относятся к истцу, а не к третьему лицу (необходимо 
доказать, что читатели могут идентифицировать того, о ком идет речь в публикации); в-третьих, что именно предполагаемый нарушитель прав истца несет ответственность за публикацию рассматриваемых данных.

Как только эти вопросы будут установлены, бремя опровержения аргументов истца переходит к ответчику, который должен убедить судью и / или присяжных, что рассматриваемая фраза содержит правдивые данные, справедливые оценки или что было получено согласие истца на публикацию данных (нельзя исключать, что истец руководствовался правилом «любое упоминание в прессе, кроме некролога, это реклама»).

Хотя можно предположить, что лингвист-эксперт мог бы помочь отличить заявления о фактах от мнений, его помощь привлекается только на первом этапе юридического процесса, описанного выше. Задача лингвиста заключается в том, чтобы аргументированно ответить перед судьей (но не присяжными) на вопрос о том, может ли рассматриваемая фраза нести в себе диффамационный смысл.

В российской же практике лингвист также должен определить форму выражения негативной информации и ответить на вопрос, может ли прецедентное высказывание быть частью утверждения о факте. Например, высказывание содержания негативной информации о враче «Так вот у Л. на этом кладбище могил - за горизонт» по формальным признакам также является утверждением о факте, так как,

во-первых, в нем отображается логическая связь, логическое заключение (так вот...),

во-вторых, высказывание имеет грамматическую форму повествовательного невосклицательного предложения,

в-третьих, в данном фрагменте не содержатся слова и конструкции, указывающие на источник мнения или подчеркивающие уверенность / неуверенность говорящего.

Указанное утверждение следует непосредственно за обобщающим суждением «Есть известное выражение, что у каждого хирурга есть свое персональное кладбище» и представляет собой применение этого обобщающего (относящегося ко всем хирургам) выражения по отношению к врачу Л. Образное выражение (метафора) «у каждого хирурга есть свое персональное кладбище» в данном контексте имеет смысл «у каждого хирурга были пациенты, которым хирург не смог помочь остаться в живых». Конечно, в практике врача Л. тоже были случаи, когда он не смог спасти пациента.

Однако далее автор сообщает о том, что «Так вот у Л. на этом кладбище могил - за горизонт». Данное предложение включает эллиптическую метафорическую конструкцию «могил - за горизонт», которая может быть восставлена до полной формы следующим образом: У Л. на этом кладбище «могилы уходят за горизонт». В данном контексте это метафорическое выражение имеет смысл «в очень большом количестве», то есть автор сообщает в образной (метафорической) форме о том, что в деятельности Л. было очень много случаев, когда его пациенты умерли, что смертность среди его пациентов значительно превышает смертность среди пациентов других врачей.

В соответствии с существующей практикой метафоричность высказывания не освобождает автора от ответственности за его содержание, а сама по себе образная форма не может служить признаком того, что соответствующая информация представлена в форме мнения, а не в виде утверждения о факте.

\section{Литература}

1. Баранов А.H. Скрытое (имплицитное) утверждение в лингвистической экспертизе текста. URL: http://konference.siberia-expert.com/publ/baranov_a_n/1-1-0-55.

2. Будаев Э.В., Ворошилова М.Б., Руженцева Н.Б. Эволюция лингвистической экспертизы: методы и приемы. Екатеринбург, 2017.

3. Федеральный закон от 31 мая 2001 г. N 73-Ф3 «О государственной судебно-экспертной деятельности в Российской Федерации».

4. Durant A. Allusions and other 'innuendo' meanings in libel actions: the value of semantic and pragmatic evidence. Forensic Linguistics. 1996. Vol 3, No 2.

\section{References}

1. Baranov, A.N. (2018). Skrytoe (implitsitnoe) utverzhdenie v lingvisticheskoy ekspertize teksta. Available from: http://konference.siberia-expert.com/publ/baranov a n/1-1-0-55 (in Russian).

2. Budaev, E.V., Voroshilova, M.B., Ruzhentseva, N.B. (2017). Evolyutsiya lingvisticheskoy ekspertizy: metody i priemy. Ekaterinburg (in Russian).

3. Federal'nyy zakon ot 31 maya 2001 g. (2001). 73-FZ “O gosudarstvennoy sudebno-ekspertnoy deyatel'nosti v Rossiyskoy Federatsii" (in Russian).

4. Durant, A. (1996). Allusions and other 'innuendo' meanings in libel actions: the value of semantic and pragmatic evidence. Forensic Linguistics, 3(2), 195-210.

\section{Citation:}

Будаев Э.В., Ворошилова М.Б., Чудинов А.П. Анализ прецедентного высказывания в рамках судебной лингвистической экспертизы: зарубежный и российский опыт. // Юрислингвистика. - 2019. - 11. - С. 29-32.

Budaev, E.V., Voroshilova, M.B., Chudinov, A.P. (2019). The analysis of the precedent expression within forensic linguistic expertise: Russian and international experience. Legal Linguistics, 11, 29-32.

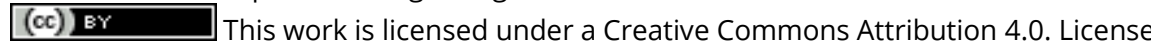

